\title{
A Case of Growth Transformation in Unexercised Limb Bones
}

\author{
Shuji TAKEUCHI \\ Department of Anatomy, Jikei University, School of Medicine
}

\begin{abstract}
The unexercised limb bones of a male patient with hydrocephalus, who had been bedridden for 16 years, were observed and measured in order to examine growth transformation and growth direction. Although length growth was not markedly disturbed, transverse growth and the thickness of periosteal deposition were delayed. These findings confirmed that stress is necessary for growth of bone thickness. No differences in the circumference and area of the medullary cavity were evident between this subject and the femora of the average adult male, in spite of the delayed thickness growth. Therefore it was considered that lack of exercise disturbs the thickness growth of bone, but does not disturb bone resorption in the medullary cavity.
\end{abstract}

Key Words Unexercised, Limb bones, Growth of bone, Transformation, Bone resorption

\section{Introduction}

Length growth of limb bones differs from growth in thickness. As stated in GRAY's Anatomy (WILLIAMS and WARWICK, 1989) and Principles of Anatomy and Physiology (TORTORA and ANAGNOSTAKOS, 1987), an increase of epiphyseal cartilage contributes to growth in the length and thickness of bone through continuous subperiosteal deposition and endosteal erosion.

Recently an opportunity arose to dissect and study the body of a male patient with hydrocephalus, who had been bedridden for 16 years. The limb bones were pathologically thin, but there was no difference in their length between this patient and the average adult male. Retarded thickness periosteal growth was evident, but there was little retardation of length cartilaginous growth. The direction of bone growth relative to stress was examined using materials from this patient.

\section{Subject and Observations}

The subject was a Japanese male patient with hydrocephalus, who had died aged 16 years and 1 month. He had been bedridden since admission to the National Higashinagano Hospital. The head girth was $754 \mathrm{~mm}$, extremely large in comparison with the average $(559.8 \mathrm{~mm})$ for a Japanese aged 16 years (Japanese Standards Association, 1984). The volume of cerebrospinal fluid was $2,800 \mathrm{ml}$ and the weight of brain 1,845 g. During life, the patient had been unable to move his head unaided, and had lain with the left side of the face in contact with the bed. He had been lying in a supine position, with the left shoulder in contact with the bed. Scoliosis and

Article No. 9031 Received June 18, 1991 
antero-posterior torsion of the spine were observed. The head of the femur was not well developed, the acetabulum was shallow, and no formation of the acetabular tegmen was detected because of luxatio coxae congenita. The left sides of both knees had been in contact with the bed because of the congenital luxation of the hip joint.

Chondral ossification was observed at the acromial and sternal ends of both clavicles, the distal end of the right radius, the styloid processes of both ulnae, and the proximal ends of both fibulae. The epiphyseal junctions of other long bones appeared to be ossified.

\section{Methods}

Measurements taken were those defined by MARTIN and SALLER (1957). The data obtained from the patient were compared with data reported for modern Japanese bones (OHBA, 1950; SUZUKI, 1961; ARAI, 1973; EBINA, 1951; FUKUDA, 1961; MORITA, 1950; NISHIHARA, 1953; TAKANO, 1958a, b), the difference being expressed as percentages relative to the average or relative to the standard deviation.

Cross-sectional images of the femora were obtained using a CT-scanner (HITACHI CTW340). Forty-four right femora (from males aged 16-29 years) from the collection of the Department of Anatomy, Jikei University School of Medicine, were used for CT-scan comparison. The cross-sectional area and the circumference at the mid-shaft and the medullary cavity of the femora were calculated from the photographs with the aid of a digitizer (GRAFTEC KD3800).

\section{Results}

The measurement data for the upper limb bones are shown in Table 1.

Clavicle

A difference in the maximum length between right and left was found. The left bone was short (maximum length: $122 \mathrm{~mm}$ ), and showed strong curvature of the shaft (23.8) in comparison with the right side. The mid-shaft circumferences of both the right and left bones were $33 \mathrm{~mm}$. The arc lengths of the shaft curvature were $112 \mathrm{~mm}$ (right) and $106 \mathrm{~mm}$ (left).

\section{Scapula}

A difference in the coracoid process between right and left was found, the right being larger than the left. The vertical diameter was $7.4 \mathrm{~mm}$ (right) and $6.3 \mathrm{~mm}$ (left) at the mid-point of the maximum length of the coracoid. The sagittal diameter was $12.7 \mathrm{~mm}$ (right) and $9.2 \mathrm{~mm}$ (left), and the circumference of the mid-point was 36 $\mathrm{mm}$ (right) and $28 \mathrm{~mm}$ (left).

\section{Humerus}

The proximal epiphyseal line was well defined, and resembled a shallow groove. The crest of the lesser tubercle was not defined, but the crest of the greater tubercle was sharp (Fig. 1a). In particular, the left crest of the greater tubercle protruded and showed medial deviation. The deltoid tuberosity was faintly evident. The radial nerve sulcus was not found. In cross-section, the mid-shaft of the right humerus was columnar in shape, with compression at the antero-medial and posterior surfaces (Fig. 1b); the left mid-shaft showed a columnar shape with compression at the medial and lateral surfaces. The distal parts of both bones showed a deltoid columnar shape (Fig. 1c), their anterior edges were sharp, and the antero-lateral and posterior surfaces were narrow.

Radius

The distal end of the right radius showed chondral ossification. The radial tuberosity was normal. The transverse diameter and the circumference were small. 
Table 1. Measurements in $\mathrm{mm}$ and indices of upper limbs

\begin{tabular}{|c|c|c|c|c|c|c|c|}
\hline \multirow{2}{*}{\multicolumn{2}{|c|}{ Item with MARTIN's number ${ }^{l)}$}} & \multirow{2}{*}{$\frac{\text { Hydrocephalus }}{\mathrm{H}}$} & \multicolumn{3}{|c|}{ Recent Japanese } & \multicolumn{2}{|c|}{ Difference } \\
\hline & & & $\mathrm{N}$ & $\mathrm{M}^{2}$ & $\overline{\mathrm{SD}}$ & $100[\mathrm{H}-\mathrm{M}] / \mathrm{M}$ & {$[\mathrm{H}-\mathrm{M}] / \mathrm{SD}$} \\
\hline \multicolumn{3}{|c|}{ Clavicle (right) } & \multicolumn{5}{|c|}{ (TAKANO, 1958a) } \\
\hline 1 & Max. length & 142 & 125 & 139.6 & 9.8 & 2 & 0.2 \\
\hline $2 \mathrm{a}: 1$ & Index of curvature & 18.3 & 125 & 22.1 & 2.1 & -17 & -1.8 \\
\hline 4 & Vert. diam. of mid-shaft & 9 & 125 & 10.0 & 1.4 & -10 & -0.7 \\
\hline 5 & Sagit. diam. of mid-shaft & 11 & 125 & 12.2 & 1.7 & -10 & -0.7 \\
\hline $4: 5$ & Index of cross-section & 81.8 & 124 & 83.4 & 13.0 & -2 & -0.1 \\
\hline 6 & Circumf. of mid-shaft & 33 & 125 & 38.2 & 4.1 & -14 & -1.3 \\
\hline $6: 1$ & L-T index & 23.4 & 125 & 27.3 & 3.1 & -14 & -1.3 \\
\hline \multicolumn{3}{|c|}{ Scapula (right) } & \multicolumn{5}{|c|}{ (TAKANO, 1958b) } \\
\hline 1 & Anatomical width & 133 & 124 & 149.3 & 9.3 & -11 & -1.8 \\
\hline 2 & Anatomical length & 80 & 124 & 98.2 & 5.3 & -19 & -3.4 \\
\hline $2: 1$ & W-L index & 60.2 & 125 & 66.1 & 3.4 & -9 & -1.7 \\
\hline $6: 2$ & Supraspin. index & 50.0 & 124 & 42.3 & 5.2 & 18 & 1.5 \\
\hline 12 & Length of glen. cav. & 35 & 124 & 35.2 & 2.5 & -1 & -0.1 \\
\hline 13 & Width of glen. cav. & 21 & 124 & 26.8 & 2.3 & -22 & -2.5 \\
\hline $13: 12$ & L-W index of glen. cav. & 60.0 & 125 & 76.2 & 5.0 & -21 & -3.2 \\
\hline 15 & Angle between L-W & 79 & 125 & 88.2 & 3.1 & -10 & -3.0 \\
\hline \multicolumn{3}{|c|}{ Humerus (right) } & \multicolumn{5}{|c|}{ (NISHIHARA, 1953) } \\
\hline 1 & Max. length & 305 & 70 & 295.9 & 16.9 & 3 & 0.5 \\
\hline 3 & Upper epiph. width & 43 & 70 & 48.3 & 2.7 & -11 & -2.0 \\
\hline 4 & Bicondylar width & 48 & 70 & 59.0 & 3.7 & -19 & -3.0 \\
\hline 5 & Max. diam. of mid-shaft & 16 & 70 & 22.4 & 1.8 & -29 & -3.6 \\
\hline 6 & Min. diam. of mid-shaft & 11 & 70 & 17.7 & 1.6 & -38 & -4.2 \\
\hline $6: 5$ & Index of cross-sec. & 68.8 & 70 & 79.6 & 4.7 & -14 & -2.3 \\
\hline 7 & Least circumference & 45 & 70 & 62.3 & 4.3 & -28 & -4.0 \\
\hline $7: 1$ & L-T index & 14.9 & 70 & 21.1 & 1.6 & -29 & -3.9 \\
\hline 10 & Sagit. diam. of head & 39 & 70 & 44.2 & 3.0 & -12 & -1.7 \\
\hline $12 \mathrm{a}$ & Width of troch. \& cap. & 34 & 70 & 40.8 & 3.2 & -17 & -2.1 \\
\hline 14 & Width of olec. fossa & 24 & 70 & 27.0 & 1.8 & -11 & -1.7 \\
\hline 16 & Cond.-shaft angle & 93 & 70 & 81.1 & 3.4 & 15 & 3.5 \\
\hline 18 & Torsion angle & 129.7 & 70 & 152.7 & 5.2 & -15 & -4.4 \\
\hline \multicolumn{3}{|c|}{ Ulna (right) } & \multicolumn{5}{|c|}{ (EBINA, 1951) } \\
\hline 1 & Max. length & 239 & 64 & 241.5 & 10.3 & -1 & -0.2 \\
\hline $6(1)$ & Width of upp. epiph. & 22 & 64 & 31.5 & 2.4 & -30 & -4.0 \\
\hline 11 & $D-V$ diam. of shaft & 11 & 64 & 13.2 & 1.1 & -17 & -2.0 \\
\hline 12 & Transv. diam. of shaft & 8 & 64 & 16.3 & 1.1 & -51 & -7.5 \\
\hline $11: 12$ & Index of cross-sec. & 137.5 & 64 & 80.9 & 7.3 & 70 & 7.8 \\
\hline $3: 2$ & L-T index & 12.3 & 64 & 17.5 & 1.3 & -30 & -4.0 \\
\hline \multicolumn{3}{|c|}{ Radius (left) } & \multicolumn{5}{|c|}{ (EBINA, 1951) } \\
\hline 1 & Max. length & 228 & 64 & 223.7 & 10.0 & 2 & 0.4 \\
\hline 2 & Physi. length & 214 & 64 & 207.3 & 8.8 & 3 & 0.8 \\
\hline 3 & Min. circumference & 26 & 64 & 40.4 & 2.8 & -36 & -5.1 \\
\hline 4 & Transv. diam. of shaft & 12 & 64 & 16.5 & 1.4 & -27 & -3.2 \\
\hline 5 & D-V diam. of shaft & 7 & 64 & 11.7 & 1.0 & -40 & -4.7 \\
\hline $5: 4$ & Index of cross-sec. & 58.3 & 64 & 71.0 & 5.8 & -18 & -2.2 \\
\hline $4(1)$ & Transv. diam. of capit. & 18 & 64 & 21.1 & 1.3 & -15 & -2.4 \\
\hline $5(5)$ & Circumference of mid-shaft & 29 & 64 & 43.4 & 3.4 & -33 & -4.2 \\
\hline $5(6)$ & Width of lower epiph. & 24 & 64 & 33.3 & 2.2 & -28 & -4.2 \\
\hline $3: 2$ & L-T index & 12.1 & 64 & 19.6 & 1.4 & -38 & -5.4 \\
\hline
\end{tabular}

1) English version according to SUZUKI et al. (1986)

2) Mean for recent Japanese 


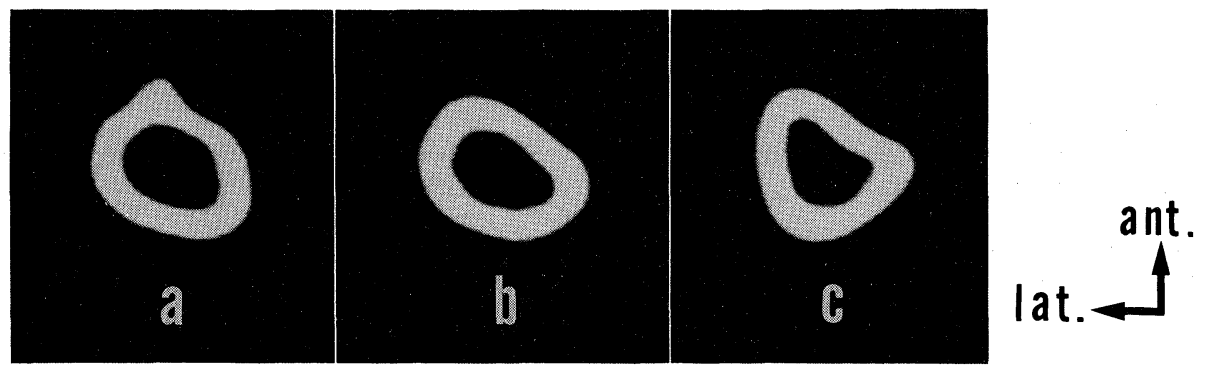

Fig. 1. CT cross-section image of the right humerus of a hydrocephalic patient: a. proximal $1 / 4$ level; b. mid-shaft level; c. distal $1 / 4$ level.

Ulna

The distal ends of both ulnae were not ossified and the styloid process showed chondral ossification. The ulnar tuberosity was ill-defined, in contrast to the radial tuberosity, showed a normal pattern. The supinator crest was observed, and the interosseous border at the distal third of the shaft showed slight lateral protrusion. The crest of attachment of the pronator quadratus was continuous with the interosseous border.

The measurements of the right lower limb bones are shown in Table 2.

\section{Femur}

Both femoral heads were less developed than normal, and showed a large degree of torsion (right 4.9 SD, left 2.9 SD), resulting in twisting of the upper part of the shaft (Fig. 2b). The right torsion angle was greater than the left (right $59^{\circ}$, left $38^{\circ}$ ). These angles were also greater than those of the average Japanese $\left(12.4^{\circ}\right)$. Prominent protrusion of the greater and lesser trochanters was observed, although both were not markedly large (Fig. 2a). The intertrochanteric line was not defined and the intertrochanteric crest was absent. The posterior area between the greater and lesser trochanters was largely concave. The gluteal tuberosity was not elevated, but was prolonged to the linea aspera. The medial and lateral lips of the linea aspera were not definitely defined at the distal third of the shaft (Fig. 2c). The posterior margin of the linea aspera was sharp. The upper protruding part of the adductor tubercle was not well defined. The width of the articular surface was narrow from the inferior to posterior area of the medial and lateral condyles. The intercondylar fossa was largely concave.

\section{Tibia}

The tibiae showed strong torsion, as in the case of the femora. The torsion on the left side was greater than that on the right (right $21^{\circ}$, left $27^{\circ}$ ), contrary to the bilateral difference noted for the femora. The tibial tuberosity was observed as a forward eminence, but no protrusion was found. In cross-section, the upper part of the shaft showed a deltoidal columnar shape (Fig. 3a). The anterior margin and interosseous border of the lower half of the shaft could not be seen clearly. The medial, lateral and posterior surfaces of the lower half of the shaft were not flat, but convex, giving the lower half of the shaft a columnar shape (Fig. 3b). The soleal line was indefinite at the postero-superior part of the bone. The upper medial part of the shaft as far as the nutrient foramen was concave, and the sulcus was observed. The maleolar sulcus on both sides was absent.

Fibula

The heads of both fibulae showed chondral 
Table 2. Measurements in $\mathrm{mm}$ and indices of right lower limbs

\begin{tabular}{|c|c|c|c|c|c|c|c|}
\hline \multirow{2}{*}{\multicolumn{2}{|c|}{ Item with MARTIN's number') }} & \multirow{2}{*}{$\frac{\text { Hydrocephalus }}{\mathrm{H}}$} & \multicolumn{3}{|c|}{ Recent Japanese } & \multicolumn{2}{|c|}{ Difference } \\
\hline & & & $\mathrm{N}$ & $\mathrm{M}^{2}$ & $\overline{\mathrm{SD}}$ & $100[\mathrm{H}-\mathrm{M}] / \mathrm{M}$ & {$[\mathrm{H}-\mathrm{M}] / \mathrm{SD}$} \\
\hline \multicolumn{3}{|l|}{ Pelvis } & \multicolumn{3}{|c|}{ (ARAI, 1973) } & & \\
\hline 1 & Height & 151 & 115 & 206.0 & 8.1 & -27 & -6.8 \\
\hline 2 & Max. width & 192 & 115 & 255.5 & 12.1 & -25 & -5.2 \\
\hline $1: 2$ & W-H index & 78.6 & 115 & 79.8 & 3.5 & -2 & -0.3 \\
\hline 3 & Outer sagit. diam. & 158 & 115 & 165.5 & 10.1 & -5 & -0.7 \\
\hline 9 & Height of ilium & 103 & 115 & 133.6 & 7.0 & -23 & -4.4 \\
\hline 11 & Depth of iliac fossa & 5 & 115 & 7.9 & 2.3 & -37 & -1.3 \\
\hline 12 & Width of ilium & 115 & 115 & 150.3 & 6.8 & -23 & -5.2 \\
\hline $12: 10$ & Iliac index & 164.3 & 115 & 161.7 & 8.0 & 2 & 0.3 \\
\hline 15 & Height of ischium & 57 & 115 & 79.7 & 3.1 & -28 & -7.3 \\
\hline 17 & Length of pubis & 69 & 115 & 75.8 & 3.7 & -9 & -1.8 \\
\hline 22 & Max. diam. of acetab. & 38 & 115 & 53.5 & 2.2 & -29 & -7.0 \\
\hline 24 & T.diam. of pelv. inlet. & 83 & 115 & 119.1 & 5.8 & -30 & -6.2 \\
\hline 33 & Infra-pubic angle & 72 & 115 & 62.4 & 7.9 & 15 & 1.2 \\
\hline \multicolumn{3}{|l|}{ Femur } & \multicolumn{3}{|c|}{ (OHBA, 1950) } & & \\
\hline 1 & Max. length & 391 & 132 & 412.1 & 18.6 & -5 & -1.1 \\
\hline 2 & Physiological length & 384 & 132 & 408.1 & 19.4 & -6 & -1.2 \\
\hline 5 & Shaft length & 323 & 132 & 324.8 & 17.8 & -1 & -0.1 \\
\hline 6 & Sagit. diam. of mid-shaft & 18 & 132 & 27.6 & 2.2 & -35 & -4.4 \\
\hline 7 & Transv. diam. of mid-shaft & 14 & 132 & 26.2 & 2.1 & -47 & -5.8 \\
\hline $6: 7$ & Plilasteric index & 128.6 & 132 & 105.7 & 8.4 & 22 & 2.7 \\
\hline $8: 2$ & $\mathrm{~L}-\mathrm{T}$ index & 13.3 & 132 & 20.4 & 1.3 & -35 & -5.5 \\
\hline $8: 5$ & L-T index & 15.8 & 132 & 25.6 & 1.6 & -38 & -6.1 \\
\hline $10: 9$ & Platymeric index & 105.9 & 132 & 82.2 & 6.8 & 29 & 3.5 \\
\hline 13 & Upper width & 56 & 132 & 92.8 & 5.3 & -40 & -6.9 \\
\hline 15 & Vert. diam. of neck & 21 & 132 & 33.3 & 2.7 & -37 & -4.6 \\
\hline 18 & Vert. diam. of head & 31 & 132 & 46.1 & 2.8 & -33 & -5.4 \\
\hline 21 & Bi-epicondylar width & 62 & 132 & 79.7 & 4.0 & -22 & -4.4 \\
\hline 22 & Proj. length of lat. cond. & 45 & 132 & 60.3 & 3.1 & -25 & -4.9 \\
\hline $22: 21$ & Condylar index & 72.6 & 132 & 75.7 & 2.7 & -4 & $-1 . i$ \\
\hline 27 & Index of curvature & 4.4 & 132 & 3.5 & 1.0 & 26 & 0.9 \\
\hline 28 & Torsion angle & 58.7 & 132 & 12.4 & 9.5 & 373 & 4.9 \\
\hline 29 & Neck-shaft angle & 133 & 132 & 128.4 & 4.6 & 4 & 1.0 \\
\hline 30 & Condyle-shaft angle & 100 & 132 & 81.1 & 1.8 & 23 & 10.5 \\
\hline \multicolumn{3}{|l|}{ Tibia } & \multicolumn{3}{|c|}{ (SUZUKI, 1961) } & & \\
\hline 1 & Total length & 331 & 80 & 320.4 & 14.7 & 3 & 0.7 \\
\hline 3 & Width of upper epipin. & 55 & 80 & 74.6 & 3.2 & -26 & -6.1 \\
\hline 6 & Width of lower epiph. & 35 & 80 & 51.3 & 2.2 & -32 & -7.4 \\
\hline 8 & Max. diam. of mid-shaft & 13 & 80 & 28.7 & 2.1 & -55 & -7.5 \\
\hline 9 & Transv. diam. of mid-shaft & 12 & 80 & 22.8 & 1.7 & -47 & -6.4 \\
\hline $9: 8$ & Index of cross-sec. & 92.3 & 80 & 78.7 & 6.5 & 17 & 2.1 \\
\hline $9 a: 8 a$ & Cnemic index & 100.0 & 80 & 78.3 & 7.3 & 28 & 3.0 \\
\hline 10b:1 & L-T index & 10.9 & 80 & 22.7 & 1.4 & -52 & -8.4 \\
\hline 11 & Index of curvature & 1.1 & 80 & 1.9 & 0.7 & -42 & -1.1 \\
\hline 12 & Retroversion angle & 8 & 80 & 13.6 & 4.0 & -41 & -1.4 \\
\hline 14 & Torsion angle & 21 & 80 & 16.7 & 8.1 & 26 & 0.5 \\
\hline \multicolumn{3}{|l|}{ Fibula } & \multicolumn{3}{|c|}{ (FUKUDA, 1961) } & & \\
\hline 1 & Max. length & 303 & 80 & 322.4 & 15.7 & -6 & -1.2 \\
\hline 2 & Max. diam. of mid-shaft & 7 & 80 & 14.8 & 1.5 & -53 & -5.2 \\
\hline 3 & Min. diam. of mid-shaft & 6 & 80 & 10.9 & 1.1 & -45 & -4.5 \\
\hline $4(2)$ & Width of lower epiph. & 15 & 80 & 19.8 & 1.6 & -24 & -3.0 \\
\hline $4(a): 1$ & L-T index & 5.0 & 80 & 11.7 & 1.3 & -57 & -5.2 \\
\hline
\end{tabular}

1) English version according to SUZUKI et al. (1986)

2) Mean for recent Japanese 

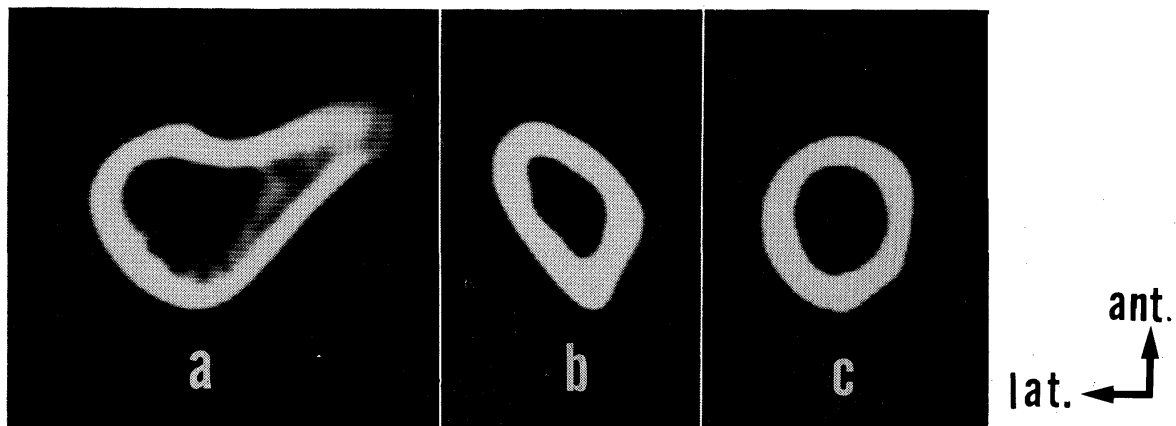

Fig. 2. CT cross-section image of the right femur of a hydrocephalic patient: a. lesser trochanter level; b. proximal $1 / 4$ level; c. distal $1 / 3$ level.
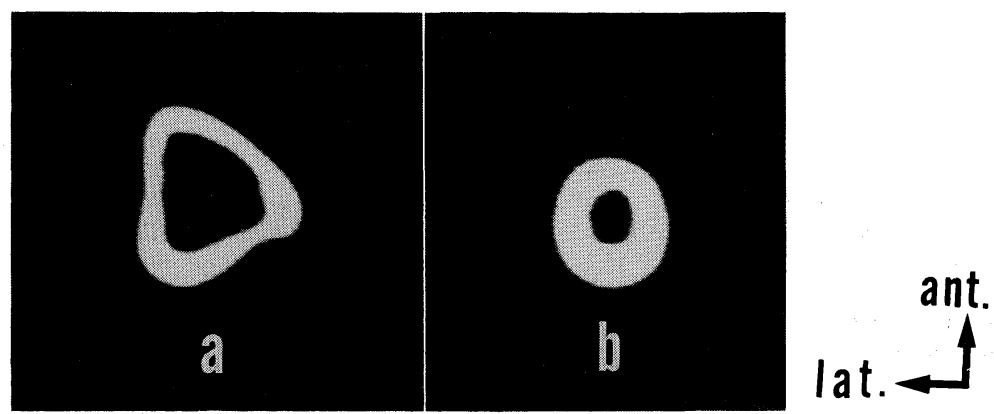

Fig. 3. CT cross-section image of the right tibia of a hydrocephalic patient: a. proximal $1 / 4$ level; b. distal $1 / 4$ level.

ossification, and the anterior margin showed a rounded edge. In cross-section, the shaft did not appear deltoidal columnar in shape, but square columnar. No concavity of the medial surface was observed. The shaft was curved anteromedially, rather than postero-laterally.

\section{Discussion}

One of the essential factors affecting bone transformation is excessive secretion of growth hormone. However, it appeared that this had not occurred in the present patient because of the significantly shorter length of the long bones compared with the normal average Japanese adult, and the absence of any delay of bone age.

A brief description of the bones in the present patient have already been given by TAKEUCHI $e t$ al. (1989). The head of the femur did not articulate with the acetabulum, and the left sides of both knees had been in contact with the bed because of congenital luxation of the hip joint. The thigh from the inguinal area to the knee was partly twisted to the left because of the position of the pelvis during supine lying. Therefore the torsion angle of the femur was large. The right thigh showed internal rotation and the left external rotation because both thighs were twisted to the left. For this reason, the right torsion angle of the femur, which had been subjected to continuous internal rotation, was greater than the left.

Bone transformation was also observed in the upper limbs. The left shoulder had been in contact with the bed due to the large head being 
turned toward the left. For this reason, a difference between the right and left clavicles was observed. However there was not much difference between the circumferences at the midshaft and the length of the arc of the shaft curvature. Therefore this transformation of the clavicle was due to continuous compression, and not to growth transformation. SCOTT (1957), in describing bone transformation, stated that growing bone is changed by outer stress, whereas mature bone is not changed to a great extent. The observed transformation of the left clavicle was thus due to external stress on the growing bone (SCOTT, 1957).

A large difference between the right and left scapulae was also found. The right coracoid process was larger than the left, because the left upper limb had not moved much due to the left shoulder having been in contact with the bed, although the right upper limb had been moved relatively more than the left. Healthy bones are larger than atrophied bones (HAMADA et al., 1967, 1968). The difference in thickness between the right and left coracoid processes, to which the short head of the biceps brachii, the coracobrachialis and the pectoralis minor muscles are attached, was due to the difference in the quantity of mechanical stress during the growth period. One report has described a difference in bone transformation between the right and the left (ISHIDA and SUZUKI, 1985) due to disuse atrophy of the limbs after childhood poliomyelitis. There have been a few studies on the influence of childhood paralytic disease on skeletal growth (HUMPHRY, 1862; HOWELL, 1917; TOWER, 1937). These studies showed that growth of bone length and breadth was suppressed in atrophic long bones, and that the

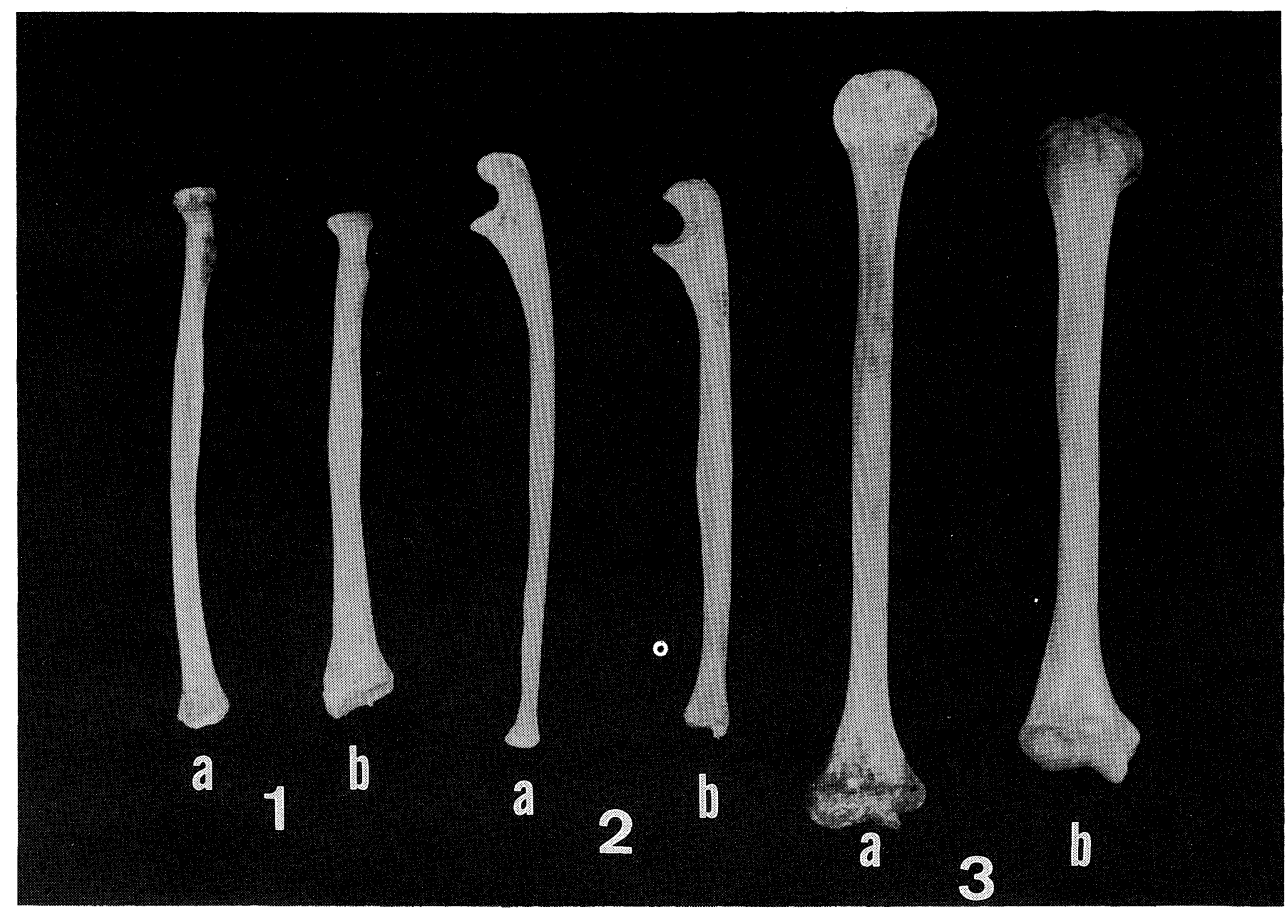

Fig. 4. Upper limb bones of a male patient with hydrocephalus (a) and a normal female aged 20 (b): 1. right radius; 2 . right ulna; 3 . right humerus. 


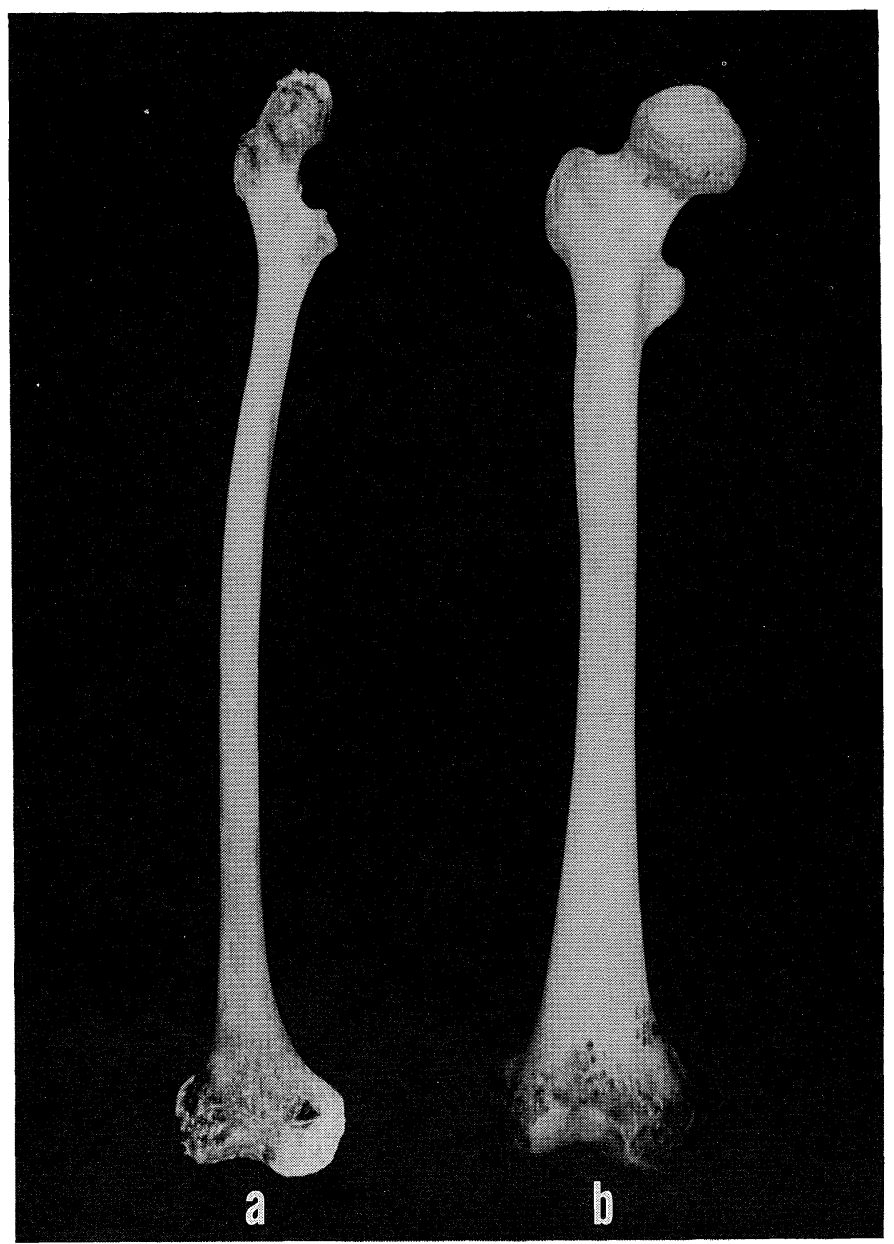

Fig. 5. Right femur of a male patient with hydrocephalus (a) and a normal female aged 20 (b).

transverse growth of long bones was more markedly disturbed than the axial growth.

The same tendency was observed in the present case. In Figs. 4, 5, 6, the right radius, ulna, humerus, femur, fibula and tibia of the patient are shown in comparison with the right bones of a normal adult female aged 20 years. The length-thickness indices for all the long bones were much smaller in the patient compared with the female control, whose bones were smaller in size than the average normal value for recent Japanese males.
In Table 3, the length of each long limb bone, the circumference of the mid-shaft, the sagittal and the transverse diameter, and indices are compared with those of the normal average Japanese adult as reported in the studies cited in the Methods. Each of the diameters and L-T index at the mid-shaft was small in comparison with the average. In the upper limb, the humerus and radius were slightly longer than average, but the length of the ulna was almost the same (Fig. 7). Thus no delay in length growth was observed. However the size of the epiphyseal bone was 


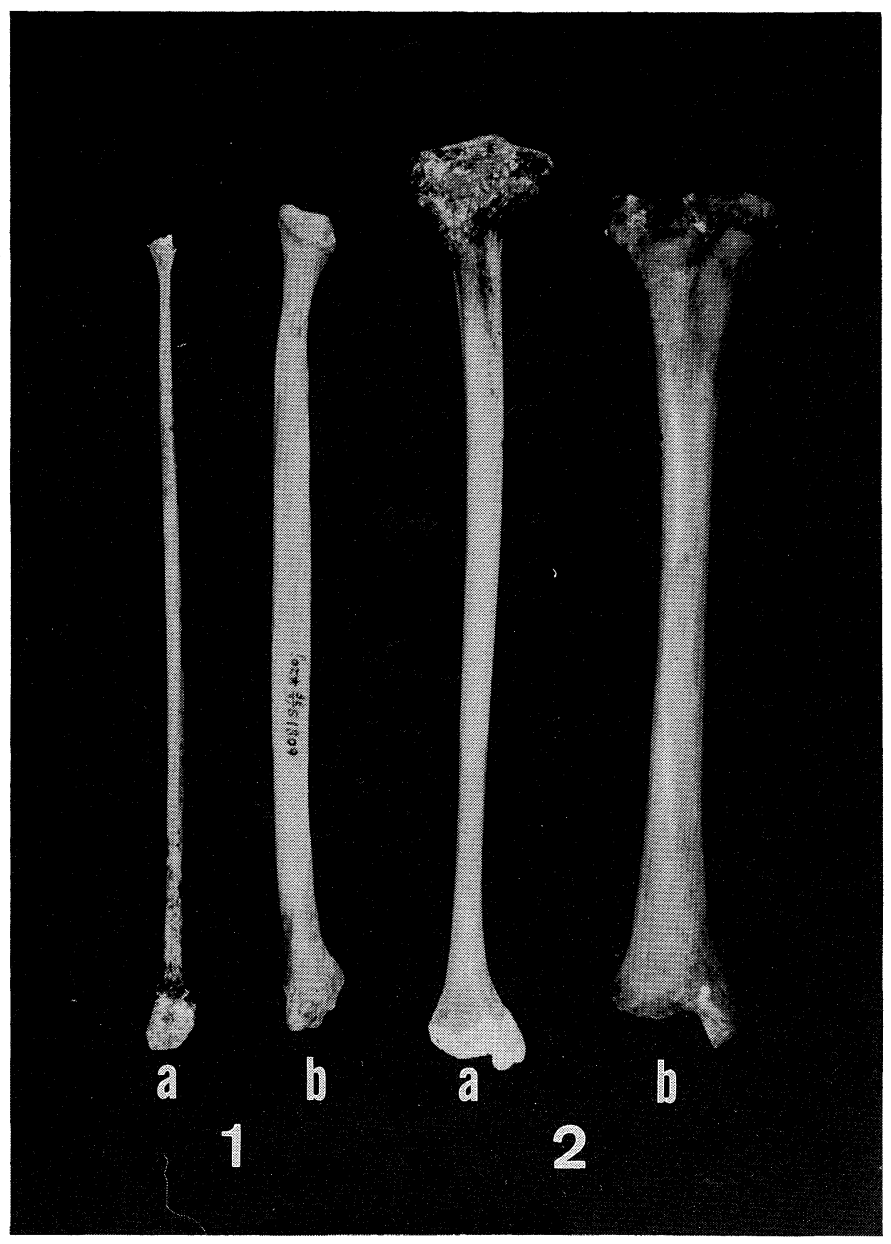

Fig. 6. Lower limb bones of a male patient with hydrocephalus (a) and a normal female aged 20 (b): 1 . right fibula; 2 . right tibia.

small (range: $-2 \mathrm{SD}$ to $-3 \mathrm{SD}$ ), and the thickness of the epiphyseal bone was much smaller (-4SD). The length-thickness index was also small (-4SD), and the lower limbs had almost the same tendency (Fig. 8). The head of the femur showed arrested development because of congenita luxatio coxae. Bone transformation such as strong torsion of the femur due to the abnormal position of the patient was observed. For these reasons, the delay in the growth of the lower limb bones was much more obvious than in the upper limbs. However, definite delay in growth of the lower limb bones was observed, compared with the upper limbs, because of the congenita luxatio coxae and arrested development of the femoral head. Reports stating that the growth in thickness of the limb bones was delayed were the result of comparing the atrophied side and the healthy side (ISHIDA and SUZUKI, 1985; OMORI and ISHIDA, 1948, 1950).

In experiments using animals, MAASS (1901) set the hind leg of rabbit in a cast, and SHIMIZU (1941) amputated the forelimb of rat at the right elbow, leaving the proximal part on the body. 
Table 3. Comparison of long bones between hydrocephalic male $(\mathrm{H})$ and recent Japanese males $(\mathrm{J})$

\begin{tabular}{|c|c|c|c|c|c|c|c|}
\hline & & Length & $\begin{array}{l}\text { Circum- } \\
\text { ference }\end{array}$ & $\begin{array}{l}\text { Sagit. } \\
\text { diam. }\end{array}$ & $\begin{array}{l}\text { Transv. } \\
\text { diam. }\end{array}$ & $\begin{array}{l}\text { Index of } \\
\text { cross-section }\end{array}$ & $\begin{array}{l}\text { Length-thickness } \\
\text { index }\end{array}$ \\
\hline \multirow[t]{2}{*}{ Humerus } & $-\mathrm{H}$ & 305 & 46 & 16 & 11 & 68.8 & 14.9 \\
\hline & $-\mathrm{J}$ & 295.9 & 66.2 & 22.4 & 17.7 & 79.6 & 21.1 \\
\hline \multirow[t]{2}{*}{ Radius } & $-\mathrm{H}$ & 228 & 29 & 7 & 10 & 70.0 & 13.6 \\
\hline & $-\mathbf{J}$ & 223.7 & 43.4 & 12.2 & 15.6 & 78.3 & 21.1 \\
\hline \multirow[t]{2}{*}{ Ulna } & $-\mathrm{H}$ & 211 & 26 & 11 & 8 & 137.5 & 12.3 \\
\hline & $-\mathbf{J}$ & 210.7 & 36.6 & 13.2 & 16.3 & 80.9 & 17.5 \\
\hline \multirow{2}{*}{ Femur } & $-\mathrm{H}$ & 323 & 51 & 18 & 14 & 128.8 & 15.8 \\
\hline & $-\mathbf{J}$ & 324.8 & 83.6 & 27.6 & 26.2 & 105.7 & 25.6 \\
\hline \multirow[t]{2}{*}{ Tibia } & $-\mathrm{H}$ & 335 & 41 & 13 & 12 & 92.3 & 10.9 \\
\hline & $-\mathbf{J}$ & 325.3 & 79.0 & 28.7 & 22.8 & 78.7 & 22.7 \\
\hline \multirow[t]{2}{*}{ Fibula } & $-\mathrm{H}$ & 303 & 23 & 7 & 6 & 85.7 & 5.0 \\
\hline & $-\mathbf{J}$ & 322.4 & 43.4 & 14.8 & 10.9 & 73.4 & 11.7 \\
\hline
\end{tabular}

Max. length

$\Delta$ Max. length $(L)$

*Physio. length

Upper epiph. width

Bicond. width

$\Delta$ Transv. diam. of capit. (L)

* Width of olecranon

Circumf. of mid-shaft

$\Delta$ Circumf. of mid-shaft (L)

* Least circumf. of shaft

$L$ - $T$ index

$\Delta L-T$ index $(L)$

$* \mathrm{~L}-\mathrm{T}$ index

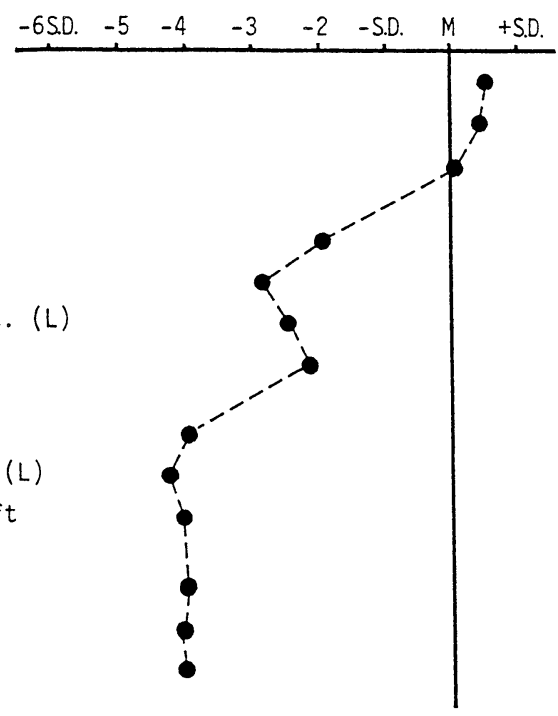

Humerus $\Delta$ Radius * Ulna

Fig. 7. Deviation graph of upper limb bones. M: mean for recent Japanese.

These experiments also revealed that the growth in thickness of the limb bones was delayed.

The growth in the length of the upper and lower limb bones was not delayed in our patient, but there observed delayed growth in thickness. This tendency agrees with that in the previous studies (HUMPHRY, 1862; HOWELL, 1917; TOWER, 1937). However, difference between upper and lower limb bones in delayed growth as observed in our subject has not been described in previous reports. Such a difference in growth suggests that there is a difference in the quality and quantity of stress between the upper and lower limb bones. Since the male patient we examined had been bedridden for 16 years, he had never been in an upright position, and 


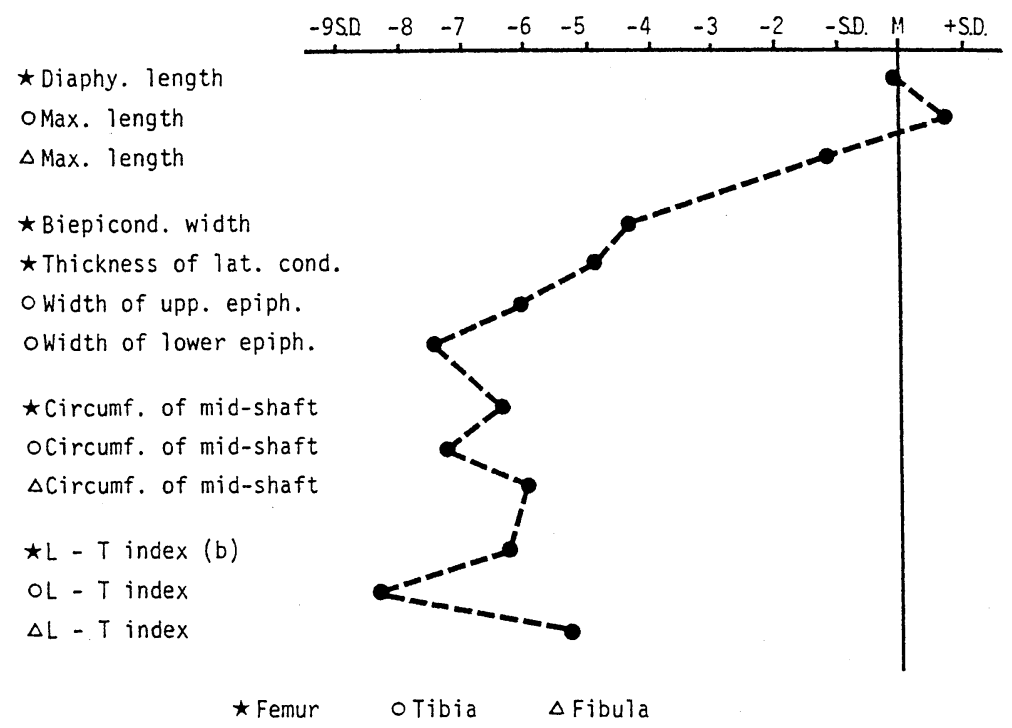

Fig. 8. Deviation graph of lower limb bones. M: mean for recent Japanese.

therefore his lower limb bones had not been placed under axial stress. Normally, the lower limb bones are under stress due to muscle action and also due to the body weight. The growth in thickness of the lower limb bones was markedly delayed in our patient probably because the bones had not been subjected to very much of either of these stresses.

This suggests that the delayed growth in the thickness of the lower limb bones was due to disturbance of bone deposition. However, bone absorption was not very much disturbed. Fig. 9 shows a CT-scan cross-section of the materials; one is the mid-shaft of the femur from the male patient with hydrocephalus, and the other is the same region of the femur from a male aged 21 years. Both femurs are of the same length, but the medullary cavity of the male patient is large despite the thinness of the shaft. The thickness of adult limb bones increases with age (SELDIN, 1964; TAKEUCHI et al., 1990). For this reason, subjects used for comparison by CT-scan should be of similar ages.

The average cross-sectional area, the circum-

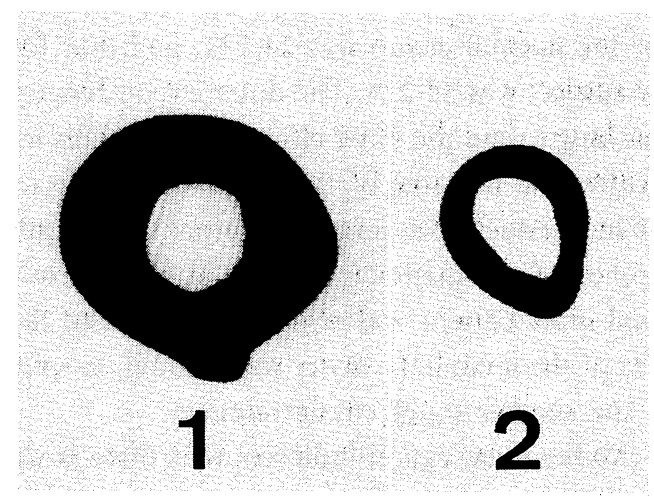

Fig. 9. CT cross-section image at the mid-shaft of femur: 1. normal male aged $21 ; 2$. male patient with hydrocephalus.

ference of the shaft, the area of the medullary cavity, the circumference of the medullary cavity and other data for the male patient are shown in Table 4. When these materials are compared with the normal ones, the outer circumference of the shaft is $-4.64 \mathrm{SD}$, and the inner circumference of the medullary cavity is $-1.63 \mathrm{SD}$. The cross-sectional area of the shaft is $-3.97 \mathrm{SD}$ and the area of the medullary cavity is only -1.66 
Table 4. Circumference and area of right femoral mid-shaft

\begin{tabular}{lccccc}
\hline & Hydrocephal. & \multicolumn{4}{c}{ Recent } \\
\cline { 2 - 6 } & $\mathrm{H}$ & $\mathrm{N}$ & $\mathrm{M}$ & $\mathrm{SD}$ & {$[\mathrm{H}-\mathrm{M}] / \mathrm{SD}$} \\
\hline $\begin{array}{l}\text { Circumference of } \\
\text { shaft (mm) }\end{array}$ & 51 & 44 & 83.0 & 6.9 & -4.64 \\
$\begin{array}{l}\text { Circumference of } \\
\text { marrow cavity (mm) }\end{array}$ & 31 & 44 & 41.1 & 6.2 & -1.63 \\
$\begin{array}{l}\text { Area of cross } \\
\text { section (mm }{ }^{2} \text { ) }\end{array}$ & 193 & 44 & 522.5 & 83.0 & -3.97 \\
$\begin{array}{l}\text { Area of marrow } \\
\text { cavity }\left(\mathrm{mm}^{2} \text { ) }\right.\end{array}$ & 66 & 44 & 126.6 & 36.6 & -1.66 \\
\hline
\end{tabular}

SD. The ratio of the outer circumference of the shaft compared with the inner circumference for the normal group was $49.5 \%$, and that for the subject was $60.8 \%$.

When the cross-sectional area was compared with the area of the medullary cavity, the ratio for the normal group was $24.2 \%$, and that for the subject was $34.2 \%$. The outer circumference was larger than the inner circumference. This indicates that the area of the medullary cavity of the male patient was large. Therefore the circumference of the medullary cavity of our unexercised male patient was almost normal, and the area of the medullary cavity was normal, in spite of the smaller outer circumference.

Above observation indicates that there is no correlation between resorption of the medullary cavity and additional deposition on the outer surface of the shaft. The growth in thickness of limb bones due to additional deposition is delayed due to lack of exercise, but resorption of the medullary cavity by osteoclasts is nearly normal, and growth in the length of the limb bone is not markedly delayed by chondral deposition. Consequently, mechanical stress appears to be a very important factor for acceleration of thickness growth of the long bones.

\section{Conclusion}

Growth transformation and deformation of the long limb bones of a male patient with hydrocephalus who had been bedridden for 16 years without exercise are summarized as follows:

1. Strong deformation was seen in the left clavicle (curvature of the shaft) and the upper part of the femur (torsion), which had been kept in the same position for a long time. This indicates that external stress caused bone deformation during the growth period.

2. The shaft-circumference of each long bone was smaller than the average for normal contemporary Japanese because the patient had not created stress on the bone by exercise which would have contributed to acceleration of the periosteal growth in thickness.

3. The upper and lower limb bones of the patient were thin, especially the lower limb bones. This is because the lower limbs had not been subjected to stresses from muscle action and supporting the body weight. Thus growth in thickness of the lower limb bones seems to be a result of not only the stress due to movement, but also the stress due to supporting the body weight.

4. Each length measurements was not much different from that in the normal adult, which 
suggests the mechanical stresses had very little influence on the axial growth attained by cartilaginous deposition.

5. The circumference and area of the medullary cavity showed no large difference from the normal, despite the smaller outer circumference of the shaft. Thus, lack of exercise influences periosteal growth in thickness, but not bone resorption in the medullary cavity by osteoclasts. As a result, there are no correlations between bone deposition and absorption due to lack of exercise.

\section{Acknowledgments}

I wish to express my grateful thanks to Ass. Prof. Susumu KATO, Department of Anatomy, Jikei University, School of Medicine for his useful advices throughout this work. Further, Dr. Ikuo KAGEYAMA and Miss Noriko HIGASHIBATA is gratefully acknowledged.

$$
\text { 抄録 }
$$

非運動下における四肢骨成長の変異の 1 例

竹内修二

四肢長骨の成長には, 骨端軟骨の増殖による長さ の成長と, 骨膜内面に骨質をつくり骨周囲に付加さ れる太さの成長とがあり, また, 太さの成長では, 付加増骨のみならず, 破骨細胞による䯣腔の拡大す 行われている.

この, 長骨の長さと太さとの成長の様式の違いが, 成長そのものの違いとして現れた例に遭遇した。 16 年間寝たきりの状態であった水頭症男子を剖検する 機会を得, その骨格標本の四肢長骨を観察した結果, 非常に細く病的状態を呈していた。しかしこころ の四肢骨を計測した結果, 長径では成人平均值との 間に，大きな差を見いだせなかった。っまり，成長 阻害は骨膜性の太さの成長には現れたが, 軟骨性の 長さの成長はさほど阻害されておらず, 成長の遅延 はなかった，また，骨体中央の周径及び断面積が成 人平均值と比較して非常に小さく細いのに, 䯣腔の 周径及び面積は成人平均值と余り差はなかった。成 長期の長期間にわたる非運動下における骨形態の変
異を示すと考えられるこの資料をむとにして，負荷 に対する骨の適応的成長の方向性等に付いての, 次 のような考察を行った。

1. 各長骨の骨体の周径が, 正常な現代日本人成人 平均值と比較して非常に細いのは, 非運動下におい て力学的負荷が余り与えられなかったためであり, 骨膜性の太さの成長促進には力学的負荷を要する.

2. 同じく細い骨体を持つ上肢骨と下肢骨を比べる と下肢骨の方がより細いのは, 筋運動による力学的 負荷と, 体重の支持による力学的負荷の両負荷がほ とんど掛からなかったためであり, 下肢の太さの成 長には運動による負荷のみならず身体荷重負荷が促 進の要因となっている.

3. 各長径が, 成人平均値と比較して差がないこと から, 軟骨性增殖による長さの成長に力学的負荷は 殆ど影響を与えない。

4. 骨体の周径が細い割に, 髄腔の周径, 面積には 成人平均值とあまり差がないことから, 骨膜性の太 さの成長に影響を与えた運動の欠如は, 破骨細胞に よる䯣腔の骨吸収には影響しない。 その結果, 非運 動下では増骨付加と破骨吸収とは相関しない。

\section{References}

ARAI, S., 1973: Anthropological study on Japanese bony pelves in Kanto district. Tokyo Jikeikai Med. J., 88: 1-48 (In Japanese with English summary).

EBINA, C., 1951: Anthropological study of the Japanese forearm bones. Rep. Dep. Anat. Jikei Univ. Sch. Med., 5 (In Japanese).

[蛯名忠次郎, 1951 : 日本人前腕骨の人類学的研究. 慈恵医大解剖業績, 5.]

FUKUDA, T., 1961: Anthropological study of the Japanese fibula in the Kanto district. Rep. Dep. Anat. Jikei Univ. Sch. Med., 22 (In Japanese).

[福田佐, 1961 : 関東地方人腓骨の人類学的研究. 慈恵医大解剖業績, 22.]

HAMADA, R., M. SUENAGA, Y. IJUIN and S. MORIGUCHI, 1967: Anatomical studies on the atrophied lower limb by cerebral infarction. Kagoshima Univ. Med. J., 18: 997-1001 (In Japanese with English summary).

HAMADA, R., M. SUENAGA, T. SOEJIMA, M. MIYANOHARA, Y. FUKUMOTO and T. SHIMABUKURO, 1968: Anatomical studies on the atrophied upper limb by old cerebral infarction with amputated fingers. Kagoshima Univ. Med. J., 20: 338-342 (In Japanese with English summary).

HOWELL, J.A., 1917: An experimental study of the effect of stress and strain in bone development. Anat. Rec., 13: 233-252. 
HUMPHRY, G.M., 1862: On the influence of paralysis, disease of the joints, disease of the epiphyseal lines, excision of the knee, rickets, and some other morbid conditions, upon the growth of the bones. Med. Chir. Trans. London, 45: 283-325.

ISHIDA, H. and T. SUZUKI, 1985: An osteological study of disused atrophic bones after childhood poliomyelitis. J. Anthrop. Soc. Nippon, 93: 447-460 (In Japanese with English summary).

Japanese Standards Association, 1984: Anthropometrical Report on the Physique of the Japanese, p. 137 (In Japanese).

[日本規格協会, 1984 : 日本人の体格調查報告書, p. 137. ]

MAASS, H., 1901: Über mechanische Storungen des Knochenwachstums. Arch. Pathol. Anat. Physiol. für klin. Med., 168: 185-208.

MARTIN, R. and K. SALLER, 1957: Lehrbuch der Anthropologie, 3 Aufl., Bd. 1, Gustav Fischer, Stuttgart.

MORITA, S., 1950: Anthropological study on the Japanese skulls in Kanto district. Rep. Dep. Anat. Jikei Univ. Sch. Med., 3 (In Japanese).

[森田茂, 1950 : 関東地方人頭蓋骨の人類学的研究. 慈恵医大解剖業績, 3.]

NiSHIHARA, S., 1953: Anthropological study on the Japanese humerus in Kanto district. Rep. Dep. Anat. Jikei Univ. Sch. Med., 9 (In Japanese).

[西原四良, 1953 : 関東地方人上腕骨の人類学的研 究. 慈恵医大解剖業績, 9.]

OHBA, S., 1950: Anthropological study on the Japanese femur. Rep. Dep. Anat. Jikei Univ. Sch. Med., 3 (In Japanese).

[大場信次, 1950 : 日本人大腿骨の人類学的研究. 慈恵医大解剖業績, 3.]

OMORI, A. and H. ISHIDA, 1948: Anatomical studies on the functional adaptation of the pathological limb. (1) J. Kagoshima Med. Soc., 21: 3-6 (In Japanese). [大森浅吉・石田弘, 1948 : 病的四肢の機能応化に 関する解剖学的研究. 第一報告 股関節が仮関節 を形成する下肢の骨格並に筋に認められたる変化 について. 鹿児島医学雑誌, $21: 3-6$.

OMORI, A. and H. ISHIDA, 1950: Anatomical studies on the functional adaptation of the pathological limb. (2) Effect of amputated hand on the Ossa et Muscle extremitatis thoracicar. Kagoshima Med. Sch. Kiyou II, 2: 81-86 (In Japanese with English summary).

SCOTT, J.M., 1957: Muscle growth and function in relation to skeletal morphology. Am. J. Phys. Anthropol., 15: 197-234.

SEDLIN, E.D., 1964: The ratio of cortical area to total cross-section area in rib diaphysis. A quantitative index of osteoporosis. Clin. Orthop., 36: 161-168.

SHIMIZU, M., 1941: The experimental study on the kineto-adaptation of bones. (The effect of the modified activity caused by the amputation of the right arm on the growth of bones) 1. On the bilateral asymmetry of the dimension and weight of bones. J. Zoology, 53: 489-497 (In Japanese with English summary).

SUZUKI, H., H. BABA and T. KAMIYA, 1986: Morphological study on the skeleton of a giant sumo wrestler, the late Mr. Dewagatake. J. Anthrop. Soc. Nippon, 94: 403-440 (In Japanese with English summary).

SUZUKI, N., 1961: Anthropological study on the Japanese tibia in the Kanto district. Rep. Dep. Anat. Jikei Univ. Sch. Med., 22 (In Japanese).

[鈴木信夫, 1961 : 関東地方人脛骨の人類学的研究. 慈恵医大解剖業績, 22.]

TAKANO, M., 1958a: Anthropological study on the Japanese clavicle in the Kanto district. Rep. Dep. Anat. Jikei Univ. Sch. Med., 18 (In Japanese). [高野元昭, $1958 \mathrm{a}$ : 関東地方人鎖骨の人類学的研究 慈恵医大解剖業績, 18.]

TAKANO, M., 1958b: Anthropological study on the Japanese scapula in the Kanto district. Rep. Dep. Anat. Jikei Univ. Sch. Med., 18 (In Japanese).

[高野元昭, $1958 \mathrm{~b}$ : 関東地方人肩甲骨の人類学的研 究. 慈恵医大解剖業績, 18.]

TAKEUCHI, S., S. SHIBATA, S. KATO and H. YAMASHITA, 1989: On the bone deformities occurred from the same posture in the bedridden. Jpn. J. Hum. Posture, 9: 43-47 (In Japanese with English summary).

TAKEUCHI, S., I. KAGEYAMA and S. KATO, 1990: Age change at the mid-shaft of the femur. J. Anthrop. Soc. Nippon, 98: 185.

TORTORA, G.J. and N.P. ANAGNOSTAKOS, 1987: Principles of Anatomy and Physiology, 5th ed., Harper and Row, New York.

TOWER, S.S., 1937: Trophic control of nonnervous tissues by the nervous system: A study of muscle and bone innervated from an isolated and quiescent region of spinal-cord. J. Comp. Neurol., 67: 241-267.

WILLIAMS, P.L. and WARWICK, R., 1989: GRAY's Anatomy, 37th ed., Churchill Livingstone, New York.

\section{竹 内 修 二 東京慈恵会医科大学第一解剖学教室 ₹105 港区西新橋 $3-25-8$}

Shuji TAKEUCHI Department of Anatomy, Jikei University School of Medicine 3-25-8 Nishishinbashi, Minato-ku, Tokyo 105, Japan. 